УДК 94:[351.852:7](477.43)

DOI https://doi.org/10.24919/2308-4863/37-2-10

\title{
Ганна ОЗИМОВСЬКА,
} orcid.org/0000-0003-2744-8203

магістр, викладач кафедри інструментально-виконавських дисциплін

Хмельницької гуманітарно-педагогічної академії (Хмельницький, Україна) gerbariy1234@gmail.com

\section{КУЛЬТУРНО-МИСТЕЦЬКЕ ЖИТТЯ КАМ'ЯНЕЧЧИНИ НА ПОЧАТКУ ХХ СТОЛІТТЯ}

У статті відображено початкові етапи формування професійної музичної освіти та концертно-виконавської діяльності на Поділлі, що охоплює межі 1903-1914 років ХХ століття. Розкрито питання культурно-мистецького життя Кам'яния-Подільського загалом та високого культурного рівня його існування зокрема. Щодо музичного мистецтвв, то воно потребувало значних змін перебудови. Оскільки існувала проблема відсутності музичної педагогіки на Поділлі, то ХХ століття слугувало початком професійної музичної освіти і проходженням етапів становлення професійного музичного мистецтва. Досліджено прочеси еволюиії музичної педагогіки та розвитку кониертно-виконавської діяльності, шчо сприяло вихованню иілої плеяди митців в результаті модифікачї̈ культурно-мистецького рівня краю. На початку ХХ століття відбувається складний прочес виникнення професійної музичної освіти та вплив досвіду західноєвропейських шкіл, якому сприяла діяльність музикантапедагога Тадеуша Ганицького. Проаналізовано етап формування та початковий етап існування музичної школи у Кам'янці-Подільському, його педагогічний склад з іноземних викладачів-музикантів, а також зображено концертно-виконавську діяльність школи, яка за короткий час свого існування відзначилась високим професійним рівнем підготовки мистеиько-виконавського складу. Мета полягає в дослідженні музичної освіти та концертної діяльності міста. Концертне життя міста розширило свої межі, щзо привело до суспільно-культурного розвитку, яке стало загальносуспільним явищем. Розкрито значення педагогічної діяльності Тадеуша Ганицького $i$ вплив на подальший розвиток мистецької культури Західної України.

Таким чином, діяльність Тадеуша Ганицького в освітньому та виконавському прочесі сприяла модифікації музичного мистеитва на Поділлі, зокрема на Заході України.

Ключові слова: музична педагогіка, концертно-виконавська діяльність Поділля.

Anna OZIMOVSKA, orcid.org/0000-0003-2744-8203 Master, Teacher at the Department of Instrumental and Performing Disciplines Khmelnytskyi Humanitarian-Pedagogical Academy (Khmelnytsky, Ukraine) gerbariy1234@gmail.com

\section{CULTURAL AND ARTISTIC LIFE OF KAMYANECHCHINA AT THE BEGINNING OF THE XX CENTURY}

This article reflects the initial stages of formation of professional music education and concert performance in Podillya, which covers the borders of 1903-1914 of the twentieth century. The issues of cultural and artistic life of KamianetsPodilskyi in general and the high cultural level of its existence are revealed, and as for the musical art, it required significant changes in restructuring. Just as there was a problem of lack of music pedagogy in Podillya, the twentieth century served as the beginning of professional music education and the stages of formation of professional music art. The processes of evolution of music pedagogy and development of concert-performing activity, which contributed to the education of a whole galaxy of artists as a result of modification of the cultural and artistic level of the region, are studied. At the beginning of the twentieth century there was a complex process of professional music education and the influence of the experience of Western European schools, which was facilitated by the activities of musician-teacher Tadeusz Hanytsky. The stage of formation and initial stage of existence of music school in Kamianets-Podilskyi, its pedagogical structure from foreign teachers-musicians is analyzed and the concert-performing activity of school which for short time of the existence was noted by high professional level of preparation of art-performing structure is represented. The purpose is to study the music education and concert activities of the city. The concert life of the city expanded its boundaries, which led to socio-cultural development, which became a general social phenomenon. The significance of Tadeusz Hanycki's pedagogical activity and the influence on the further development of the artistic culture of Western Ukraine are revealed.

Thus, the activity of Tadeusz Hanytsky in the educational and performing process contributed to the modification of musical art in Podillya, and in particular in Western Ukraine.

Key words: music pedagogy, concert-performing activity of Podillya. 
Постановка проблеми. Під впливом передвижників на початку XX століття у Кам'янціПодільському створюється той культурний осередок, навколо якого концентрувалась ініціативна частина суспільства. Цей період характеризувався значними соціально-економічними та суспільно-політичними змінами, що визначали шлях розвитку культури та мистецтва. Активізацію культурного життя регіону зумовили визначні творчі та педагогічні досягнення Кам'янець-Подільської художньо-промислової школи та інших навчальних закладів. Серед перших було Подільське церковне історико-археологічне товариство, засноване у 1903 році на базі Подільського єпархіального історико-статистичного комітету. Таке перетворення комітету на товариство сприяло об'єднанню краєзнавців Поділля. Так, у 1912 році у ньому налічувалось 136 членів. Окремо слід згадати діяльність Товариства мистецтв, статут якого був затверджений у січні 1908 року. Його організатором став відомий на Поділлі художник В. Розвадовський, який одночасно завідував художніми класами. Товариство мистецтв розгорнуло на Поділлі широку просвітницьку діяльність, влаштовуючи пересувні виставки художніх творів у містах та багатьох містечках губернії. Крім того, у Кам'янці-Подільському діяла постійна виставка творів мистецтв. Невід'ємним від діяльності згаданих товариств $€$ заснування у другій половині XIX - на початку XX століття у містах Подільської губернії музейних закладів. Перший музей на Поділлі з'явився у 1890 році у Кам'янціПодільському. Ініціатором його створення виступив Подільський єпархіальний історико-статистичний комітет (Урсу, 2015: 383). Стан музичної освіти та музичного мистецтва на Поділлі у XIX столітті перебував у важких умовах. Музичне мистецтво існувало на рівні домашнього музикування, запрошували знаних музикантів-педагогів з Свропи в дома місцевої знаті, тому була необхідність започаткувати спеціалізований культурний навчальний заклад, в якому можна було отримувати необхідні знання з музичного мистецтва.

Аналіз досліджень. Вивченням професійної подільської музичної культури в контексті загальнонаціонального процесу займалися в різні історичні періоди М. Печенюк, О. Гармель, Ф. Ернст, Д. Щербаківський, В. Іванов Л. Кияновська. Ця тема привертала також увагу подільських краєзнавців і музикознавців, серед яких слід назвати А. Свидницького, Р. Римар, В. Святелика, В. Циганюка, Я. Кушку, О. Пажимських, М. Ярову, П. Слободянюка, В. Іванова.
Мета статті - розкрити основні етапи розвитку музичної педагогіки у Кам'янці-Подільському на початку XX століття та проаналізувати проблеми, що виникли в процесі формування виконавсько-інструментального мистецтва.

Виклад основного матеріалу. 3 розвитком Кам'янця-Подільського як важливого промислового міста наприкінці XIX століття цілком природно виникла потреба в культурно-мистецькій освіті, що було характерною ознакою часу. Так, основним напрямом місцевої художньої освіти став художньо-промисловий, певний розквіт якого припадає на початок XX століття. Підготовка художника для промисловості та поширення елементарної художньої освіти серед населення міста стало головною метою і загальною рисою роботи названих освітніх установ. Стан культурно-мистецького життя Кам'янця набуває широкого розквіту у всіх сферах мистецького спрямування. Таким чином, музичне життя міста зазнає великих змін. 1903 рік стає переломним у мистецьких колах міста у зв'язку з появою славетно відомого й талановитого музиканта, педагога, скрипаля Тадеуша Ганицького, 3 появою якого музична культура міста переходить на інший щабель свого існування. Вона проходить довгий етап трансформації від аматорського до професійного рівня.

Т. Ганицький відразу ж почав практично підходити до питання відкриття у Кам'янці спеціалізованої музичної школи. Він сподівався на підтримку місцевих музикантів і тих фахівців, які вже працювали в місті. Вони з великою зацікавленістю відгукнулися на таку ідею. Крім того, знайшлося багато охочих навчитися музики. Шлях від ідеї до ії реалізації виявився складним. Вимагався перш за все офіційний дозвіл на заснування закладу. Підставою для цього був Статут про організацію власних навчальних закладів, затверджений Міністерством внутрішніх справ 21 жовтня 1901 року. Маючи вже досвід організації школи в Лодзі, Т. Ганицький розпочав роботу зі здійснення своєї ідеї. На вибраному ним шляху зустрілось чимало труднощів. Насамперед потрібно було розвивати питання матеріальної бази, виникли труднощі в підборі професійних кадрів. Так, Т. Ганицькому вдалося загітувати спочатку лише одного викладача А. Лозинського по класу фортепіано та теорії музики. 3 вересня 1903 року почала своє існування музична школа Т. Ганицького, і ця дата знаменується початком зародження професійної музичної освіти на Поділлі (Подолия, 1914: 5). Хоча факт заснування і реальність функціонування закладу не викликали ні в кого сумніву, все ж таки продовжували звучати недо- 
вірливі голоси. Так, в перший рік існування освітнього закладу в ньому навчалося лише 60 учнів.

На власні кошти Т. Ганицький розпочинає розбудову мистецької освіти на Поділлі. Це був фактично єдиний вихід зі складного становища. Перш за все укомплектування професійними кадрами потребувало багато зусиль. Так, запрошення висококваліфікованих педагогів з-за кордону вимагало чималих коштів, до того ж ці спеціалісти не знали ні російської, ні української мов. Останнє, як свідчать тогочасні документи, було однією з важливих перешкод у розвитку школи. Хоча доводилось якось виходити 3 місцевих умов і заохочувати до викладання кам'янецьких вчителів, директор закладу не залишав думки мати у себе справжніх професорів. У цей час він уже відкрив класи фортепіано, скрипки, теорії музики. Дітей відбирали до школи за конкурсом, звертали особливу увагу на тих, хто вже вмів грати на якомусь музичному інструменті (по нотах або на слух). У школі на них чекала досконала методика викладання 3 усіх предметів. Так, у 1904 році було відкрито T. Ганицьким додатковий (підготовчий) клас, де майбутні учні, які не мали ніяких попередніх знань, готувалися до основного курсу навчання.

У своїй праці В. Іванов надає детальний опис організації музичної освіти, у кінці першого навчального року Т. Ганицький відкрив ще один клас - вокальний, який очолила випускниця Московської консерваторії С. Булгакова. Отже, штат поповнювався професійними фахівцями, від яких директор вимагав відповідної роботи 3 учнями, а саме виховувати їх на високому методичному та фаховому рівнях, чого вимагав статут школи. Так, 14 грудня 1903 року та 25 квітня 1904 року відбулися перші концерти викладацького та учнівського складу. 3 кожним роком школа зміцнювалась, у закладі відкрилося ще два класи, а саме класи гармонії та драматичного мистецтва. У 1905 році почав діяти клас віолончелі, до якого було запрошено з Києва викладача М. Сухомлинського, його у 1906 році замінив М. Хорошанський. 3 роками кількість учнів зростала швидкими темпами, у 1905 році їх було вже 131, а в наступному - 141 . Вони вчилися у шести спеціалізованих класах, де зосередилися досить міцні виконавські сили, зокрема 3 фортепіано та струнних інструментів. Дирекція закладу часто влаштовувала учнівські звітні концерти. Лише у 1905-1906 навчальному році їх було понад десяти. Концерти мали не лише естетичне та морально-виховне, але й благодійне значення. Прибутки 3 них здебільшого переводились на потреби бідних учителів та учнів. Так, усі кошти 3 двох симфонічних концертів
Т. Ганицького було передано кам'янецькому товариству бідноти. Показовим був концерт школи у Могилеві-Подільському, кошти 3 якого пішли на користь благодійного товариства. Відомо, що лише за три роки існування школи допомога від іiі концертів складала шість тисяч карбованців (Іванов, 2007: 15).

Поява професійного музичної навчального закладу на Поділлі сприяла розвитку професійного музичного мистецтва загалом. Відбуваються численні концерти викладачів і учнів в місті, а саме в театрі, клубах, інших навчальних закладах. Концерти школи притягували до себе багато прихильників музики, і тих, хто бажав вчитися, ставало все більше. Вони були не лише з Кам'янця, але й $з$ різних повітів Волині та Поділля. Те, що концерти дійсно мали справжній успіх, підтверджують кореспондентські звіти тих часів, що публікувались на сторінках вітчизняної преси. Так, «Русская музыкальная газета» (орган Російського музичного товариства в Петербурзі) підкреслювала, що музична школа Т. Ганицького влаштовувала в Кам'янці-Подільському «найбільш серйозні» виступи (Финдейзен, 1907: 2). Наскільки вони були серйозними, дізнаємося 3 місцевих газет, де описувалися враження від почутого місцевої публіки, що бачила перед собою не учнів, а справжніх артистів, у яких їх за короткий час зумів перетворити талановитий педагог i музикант Т. Ганицький. Його ж симфонічний оркестр був дисциплінованим i талановитим колективом. Газета «Подолия» писала: «Концерт у міському клубі відбувся у переповненому залі досить вдало і викликав бурю оплесків на адресу усіх артистів-музикантів. Вокалістка Розвадовська, володіючи значним меццо-сопрано і маючи майже двооктавний діапазон, співала 3 глибоким почуттям. Артист Храмой показав публіці блискучу техніку. Поява ж на естраді хлопця Шварценштейна викликала фурор. Задушевність гри, м'якість тону, прекрасна техніка робить його талановитим музикантом. Публіка все це оцінила й тепло прийняла його, як і інших учасників концерту. Чимало сприяв успіхові вечора своїм впевненим акомпанементом В. Машкевич» (Подолия, 1906: 2).

В. Іванов пише: «Визнання школи Ганицького зростало. Зростання школи та впровадження нових навчальних дисциплін вимагало від Т. Ганицького підбору і педагогічного складу. До цього питання він ставився досить серйозно і багато зробив для піднесення високого педагогічного рейтингу школи. Про це свідчать високопрофесійні кадри, викладачі, які навчалися у відомих 
професорів світового рівня Московської, Варшавської, Паризької, Міланської, Празької консерваторій, такі як М. Петліна, В. Дальський-Рибальченко, А. Лозинський, Пік де Реплонж, 3. Комінек, Аллегранд, Іванов-Давинський, Булгакова, Сальська-Педаковська, Абрамович» (Іванов, 2007: 18).

Незважаючи на матеріальні труднощі, дуже скромні асигнування з боку Подільської губернської управи, школа все ж продовжувала працювати, а з кожним роком зростав ії авторитет. У 1907 році вона вже нараховувала вісім класів, серед яких слід назвати підготовчий, фортепіанний, скрипковий, віолончельний, вокальний, теоретичний, історичний, драматичний. У кожному 3 них працювали досвідчені педагоги та виконавці. Bce частіше до керівництва закладу зверталися музиканти $з$ питаннями щодо не лише розвитку освіти, але й організації більш жвавого музичного життя в Кам'янці і навіть у губернії. Поступово визріла ідея об'єднання місцевих музичних сил у мистецьку спілку. Т. Ганицький бере ініціативу у свої руки і разом з однодумцями у 1907 році створює «Подільське музичне товариство», в статуті якого важливими $\epsilon$ пропагування серед населення класичної музики, відкриття гуртків 3 навчання нотної грамоти, організація виконавських колективів (хорових, оркестрових), вивчення музичного фольклору.

Так, у 1913 році музична школа Т. Ганицького відсвяткувала 10-річний ювілей, який відзначився великою кількістю концертів, у яких виступили педагоги та учні школи. Місцева публіка, губернські чиновники, гості вітали ювілярів, висловлювали сподівання на подальше зростання навчального закладу, підвищення його авторитету. Звертаючись до праці В. Іванова, бачимо, що концерти на 10 річницю школи мали справжній успіх, що знову повернуло Т. Ганицького до ідеї створення міського симфонічного оркестру. Однак кам'янецька управа ніяк не могла дати згоду на існування такого колективу у своєму штатному розписі і не вважала за необхідне мати в місті подібний оркестр. Хоча оркестр завдяки неабияким зусиллям Т. Ганицького все ж таки був створений, діяв він недовго. Отже, звертаючись до очевидних фактів, говоримо про те, що він неабияких зусиль докладав до того, щоби підняти і розвинути культурно-мистецьке життя Поділля, що свідчить про справжню любов і патріотизм до рідного краю (Іванов, 2007: 19).

Як уже зазначалось, поява музичного навчального закладу істотно сприяла пожвавленню мистецького життя на Поділлі, з появою професійних колективів відбувся перехід музичного мисте- цтва на інший рівень існування. Перед Першою світовою війною Т. Ганицький встиг подарувати кам'янчанам декілька камерних та симфонічних концертів, які залишилися в їх пам'яті на багато років. Це був сміливий крок організатора заходів. Він добре розумів, що такі музичні виступи $\epsilon$ незвичними для місцевої публіки. Тадеуша Дионисовича хвилювало, чи зрозуміє та оцінить вона його задум, тому в місті була проведена попередня підготовча роз'яснювальна робота (публікація афіш, програмних листівок тощо), і ця робота виправдала себе. Газета «Подолия» потім писала: «28 січня 1914 року відбувся в Пушкінському домі перший камерний вечір, влаштований Т. Ганицьким. Концерт відбувся із заслуженим успіхом і зібрав численну публіку, яка оцінила заслуги Тадеуша Дионисовича, котрий на свої власні кошти створив у Кам'янці чудову музичну школу, що за 10 років свого існування завоювала симпатії громадськості і об'єднала навколо себе місцеві музичні сили» (Подолия, 1914: 3).

Розглядаючи репертуар концерту, відзначаємо, що успіх концерту завдячився професійним виконанням програми, що складалася 3 творів авторитетних композиторів, таких як «Серенада» Гіллера, «Квартет ре мажор» Бородіна у складі скрипалів Комінека, Загряжської, альтиста Фідлона та віолончеліста Зіберштейна, «Тріо соль мінор» Годора. Перше відділення звітного вечора закінчилося під бурхливі оплески публіки та піднесення артистам великої ліри 3 квітів. Щиро вітали також виконавців-піаністів Петліні, Максимович, Ліхтмана, які виконували твори Ліста, Городовського, Равеля. Після концерту привітали також організатора заходу Т. Ганицького (Іванов, 2007: 20).

Перший камерний концерт викликав жвавий інтерес до виступів, які планував Т. Ганицький. Він отримував численні заявки, пропозиції. Нарешті наступна така вистава планувалась на 4 лютого. Вечір відбувся у присутності великої кількості слухачів. Лунали твори Бетховена, Фібіха, Шютця та інших композиторів. 3 публікацій «Подолянина» дізнаємося, що в залі було настільки тихо, ніби там не було жодної душі, а лише лунали прекрасні мелодії. Виконавці з великим натхненням передавали характер творів, змушували слухачів віддаватися почуттям радості або суму, створювали романтичний настрій. Серед виконавців особливо виділилися скрипаль Комінек, піаністка Педаховська, альтист Зіберштейн, віолончеліст Гольдман, вокаліст Дальський (Подолянин, 1914: 3).

Отже, обидва камерні концерти були прелюдією до майбутніх симфонічних виступів, які ретельно 
готував Т. Ганицький. Перший симфонічний концерт був справжньою мистецькою подією в місті і навіть на Поділлі. «Подолия» писала, що навіть звістка про це вже наполовину «сприяла блискучому успіху виступу. Зал Пушкінського дому 1 березня був переповнений. Піднялася завіса, i Т. Ганицького зустріли бурхливими оплесками. Тут глядачі вперше побачили Т. Ганицького в ролі диригента. У рецензіях зазначалося, що п'ята симфонія Бетховена була продиригована ним із впевненістю і розумінням композиторського та виконавського стилю. Велике враження справило звучання увертюри Вагнера 3 опери «Рієнці», «Урочистого полонеза» Лядова, «Мрійливих танців» Рубінштейна, «Другої рапсодії» Ліста. У залі вирували овації» (Подолия, 1914: 7).

Прикрасою концерту був виступ відомої московської піаністки Доленго-Грабовської, запрошеної до Кам'янця Т. Ганицьким. Вона виконала декілька творів Ліста, Шопена, показала блискучу техніку, глибоку художню виразність. У газетах про іiі гру писали, що вона відчуває стиль авторів, розуміє багатство відтінків, володіє професійною інтерпретацією творів, що викликало у публіки бажання слухати ще раз виконані твори. Невипадково 7 березня був влаштований іiі сольний концерт. Вона виконувала твори Бетховена, Моцарта, Шопена, Рубінштейна. Загальна думка місцевої преси зводилась до того, що за останні роки в Кам'янці ще не чули такої чудової і професійної фортепіанної гри.

Про Т. Ганицького «Подолянин» писав: «Ганицький талановитий диригент, який вміє не лише підкорити оркестр своїй волі, але й успішно домогтися від своїх музикантів справжнього художнього виконання. Присутність на чолі оркестру диригента, який спроможний впливати на музикантів, піднімає дух виконавців. Вражає самий талант Ганицького, котрий зумів досягти такої зіграності й високого художнього виконання у короткий термін» (Подолянин, 1914: 4). «Подолия〉 назвала усі заплановані Т. Ганицьким симфонічні концерти «подією великої важливості для нашого міста», які «повинні бути занесені в художній літопис Кам'янця» (Подолия, 1914: 8).

Усі заплановані симфонічні концерти відбулися у березні на «одному диханні». Успіх другого був на рівні попереднього. На ньому висту- пив ще й соліст-віолончеліст С. Крячко - викладач Кишинівського музичного училища. У третьому концерті (22 березня) солістом був С. Шварценштейн, який знову полонив публіку своєю грою. Знов відзначалися м'якість його інтонаційного висловлювання, багатство нюансів. Не залишився поза увагою вдалий акомпанемент піаніста С. Ліпського.

Цикл симфонічних концертів завершився 25 березня i, за словами кореспондента газети «Подолия», пройшов блискуче. Як і в попередніх концертах, публіка гаряче вітала Т. Ганицького, дякуючи йому за «музичний березень», тепле ставлення до тих, хто прагнув присвятити себе музичному мистецтву. Гідно оцінила його й місцева преса: «Симфонічні концерти Ганицького $є$ світлим явищем на сірому фоні нашого провінційного міста і залишать надовго відрадну згадку»(Подолия, 1914: 5).

Останніми передвоєнними концертами, які влаштував Т. Ганицький у Кам'янці, були камерні концерти у квітні 1914 року. Вони теж пройшли блискуче. На них виступили піаніст і композитор Толкач, піаністка Максимова, співак В. Дальський, віолончелісти Розцвіт та Л. Зіберштейн, скрипалі П. Рейтер, М. Загрянський, 3. Комінек, альтист М. Фідлон. У місцевій пресі зазначалась їх висока майстерність, висловлювалась глибока подяка Тадеушу Дионисовичу: «Художні вечори T. Ганицького назавжди залишаться у пам'яті вдячних кам'янчан» (Подолия, 1914: 6).

Висновки. Отже, культурно-мистецьке життя Кам'янця-Подільського на початку XX століття набуло широкого розквіту у всіх сферах мистецтва. Так, музичне життя міста в цей час зазнало значних змін. Поява професійного музичного навчального закладу докорінно вплинула i на мистецьке життя подільського краю. На першому етапі існування музичної школи Т. Ганицького, який охопив період 1903-1914 років, було багато перешкод, але вона проіснувала довгий час i виховала цілу плеяду талановитих музикантів. Саме 3 трансформацією музичної педагогіки на Поділлі музичне мистецтво вийшло на професійний рівень, що змінило і піднесло культурномистецьке життя суспільства. Однак Перша світова війна на деякий час призупинила діяльність школи і в подальшому вона зазнала багато змін і перешкод, але не припинила свого існування досі.

\section{СПИСОК ВИКОРИСТАНИХ ДЖЕРЕЛ}

1. Іванов В. Тадеуш Ганицький (1844-1937) : монографія. 2007. С. 10-21.

2. Подолия. Газета церковно-общественная, политическая и литературная. 1914. № 14. С. 3-6.

3. Подолия. Газета церковно-общественная, политическая и литературная. 1914. № 28. С. 7-8.

4. Подолия. Газета церковно-общественная, политическая и литературная. 1914. № 38. С. 5. 
5. Подолия. Газета церковно-общественная, политическая и литературная. 1906. № 169. С. 2.

6. Подолянин. Ежедневная, политическая, общественная, и сельскохозяйственная газета. 1914. № 974. С. 3.

7. Урсу Н., Гуцул І. Культурне життя Кам'янеччини наприкінці XIX - всередині XX століття. Педагогічна освіта: теорія і практика. 2015. Вип. 18. С. 378-384.

8. Финдейзен Н. Русская музыкальная газета. 1907. № 20. С. 2.

\section{REFERENCES} nian].

1. Ivanov, V. Tadeush Hanytskyi (1844-1937). [Tadeusz Hanycki (1844-1937)]. Monograph, 2007, pp. 10-21 [in Ukrai-

2. Podolyia. Hazeta tserkovno-obshchestvennaia, polytycheskaia i lyteraturnaia. [Podolia. The newspaper is ecclesiastical, political and literary]. 1914, № 14, pp. 3-6 [in Russian].

3. Podolyia. Hazeta tserkovno-obshchestvennaia, polytycheskaia i lyteraturnaia. [Podolia. The newspaper is ecclesiastical, political and literary]. 1914, № 28, pp. 7-8 [in Russian].

4. Podolyia. Hazeta tserkovno-obshchestvennaia, polytycheskaia i lyteraturnaia. [Podolia. The newspaper is ecclesiastical, political and literary]. 1914, № 38, p. 5 [in Russian].

5. Podolyia. Hazeta tserkovno-obshchestvennaia, polytycheskaia i lyteraturnaia. [Podolia. The newspaper is ecclesiastical, political and literary]. 1906, № 169, p. 2 [in Russian].

6. Podolianyn. Ezhednevnaia, polytycheskaia, obshchestvennaia, y selskokhoziaistvennaia hazeta. [Podolyanin. Daily, political, public, and agricultural newspaper]. 1914, № 974, p. 3 [in Russian].

7. Ursu N., Gutsul I. Kulturne zhyttia Kamianechchyny naprykintsi XIX - vseredyni XX stolittia. [Cultural life of Kam'yanechchini from the 19th to the middle of the 20th century]. Pedagogical education: theory and practice, 2015. Vol. 18, pp. 378-384 [in Ukrainian].

8. Findeisen N. Russkaia muzukalnaia hazeta [Russian Musical Newspaper]. 1907, Nr. 20, p. 2 [in Russian]. 